\title{
Output Composition of the Monetary Policy Transmission Mechanism: Is Australia Different?*
}

\author{
Tuan Phan ${ }^{* *}$ \\ This version: December 2013 \\ (This is the pre-final peer-reviewed version of the following article: Phan, T. (2014), Output \\ Composition of the Monetary Policy Transmission Mechanism: Is Australia Different?. Economic \\ Record. doi: 10.1111/1475-4932.12121)
}

\begin{abstract}
This paper compares the output composition of the monetary policy transmission mechanism in Australia to those for the Euro area and the United States. Four Vector Autoregressive (VAR) models are used to estimate the contributions of private consumption and investment to output reactions resulting from nominal interest rate shocks for the period 1982Q3-2007Q4. The results suggest that the investment channel plays a more important role than the consumption channel in Australia, while the contributions of the two channels are indistinguishable in the Euro area and the U.S. The difference between Australia and the Euro area comes from differences in housing investment responses, whereas Australia is different to the U.S. mainly because it has a lower share of household consumption in total demand.
\end{abstract}

JEL classification: E52, E2

Keywords: output composition, monetary policy transmission mechanism, interest rate, housing investment, durable consumption

\footnotetext{
${ }^{*}$ The author is grateful to Ippei Fujiwara, Paul Burke, Renee Fry-McKibbin, Mardi Dungey, and two referees for comments and suggestions which help significantly improve earlier drafts of this paper. I also thank participants at a seminar at the Australian National University and the 9th BMRC-QASS Conference on Macro and Financial Economics at Brunel University for helpful discussion. Any errors remain my own responsibility.

** Crawford School of Public Policy, Australian National University, tuan.phan@anu.edu.au
} 


\section{Introduction}

It is a consensus that an increase in the policy interest rate - the main tool of monetary policy in inflation-targeting central banks ${ }^{1}$ - leads to a decline in output (Sims, 1980; Bernanke \& Blinder, 1992; Eichenbaum, 1992; Leeper \& Gordon, 1992; and Christiano et al., 1999). ${ }^{2}$ On the demand side of the goods and services market, this process operates through two main channels: investment and consumption. The former comes from an increase in the cost of capital, or a fall in the market value of firms (Tobin's q effects), followed by a decline in the private investment level. The latter refers to a decline in current private consumption due to wealth effects or inter-temporal substitution by consumers (see Boivin et al., 2010, for a recent extensive review on the channels of monetary policy transmission mechanisms).

Theories of consumption smoothing and investment volatility suggest that investment is more sensitive to changes in monetary policy compared to consumption (Modigliani \& Brumberg, 1954; Friedman, 1956; Hall, 1978; and Romer, 2011). In other words, investment is likely to react more strongly to a monetary policy shock than consumption, and therefore the investment channel is stronger than consumption channel.

The empirical evidence on the relative importance of the consumption and investment channels seems to vary by country. Angeloni et al. (2003) use Vector Autoregressive (VAR) and Dynamic Stochastic General Equilibrium (DSGE) models to conclude that whereas investment is the main transmission channel in the Euro area, the U.S. data indicate that the consumption channel plays the major role. They refer to the U.S. case as the 'output composition puzzle'. Using similar VAR models, Fujiwara (2004) concludes that the situation of Japan (using data for 1980-1996) lies somewhere between the Euro area and the U.S. cases, but the investment channel still makes the larger contribution. According to Fujiwara (2004), the most compelling reason might be related to the housing market, where changes in mortgage rates do not have significant effects on private consumption in Japan, unlike the U.S. case.

The aim of this paper is to analyse the output composition of the monetary transmission mechanism for the case of Australia and to compare it to the Euro area and the U.S. ${ }^{3}$ Australia is a small open economy which has the level of mortgage market development similar to the U.S. and much higher than in most of the countries in the Euro area (IMF, 2008; and Calza et al., 2013). Therefore, it is

\footnotetext{
${ }^{1}$ Because of the zero lower bound, some central banks are increasingly using ‘quantitative easing' and other unconventional measures instead of interest rates in implementing monetary policy. This paper focuses only on the effects of the interest rate as the main tool of monetary policy.

${ }^{2}$ Uhlig (2005) finds a 'neutral effect' on output using a sign-restricted VAR.

${ }^{3}$ I also run VARs for Japan with the same data period. However the zero lower bound of the interest rates which has been the circumstance in Japan since the 1990s leads all of the impulse responses in the VARs to be muted and inconsistent with theory. Some suggestions for an explanation can be found in Iwata and Wu (2006) and Fujiwara (2006).
} 
expected that the output composition of the monetary policy transmission mechanism in Australia is likely to be similar to the output composition of the U.S. rather than of the Euro area. Employing the similar VAR models used in Angeloni et al. (2003) and Fujiwara (2004) with a more recent period of data (1982Q3-2007Q4), the paper answers two questions: (i) is the output composition of the monetary transmission mechanism in Australia different to those in the Euro area and the U.S.?; and (ii) if so, what are the main reasons behind the differences?

For the first question, the empirical results in this paper show that in Australia, the investment channel is stronger than the consumption channel. At the same time, consumption and investment contributions are basically equal in the Euro area and the U.S. (which also means that the evidence of the 'output composition puzzle' is unclear when the recent data are used). Therefore, there is an unambiguous difference between Australia and the two comparators in terms of the output composition.

This paper then explores the second question, which has not been investigated explicitly in the previous studies. In order to find the main reasons behind the difference between Australia and the comparators, investment is decomposed into housing investment (which is believed to be more sensitive to changes in the policy rate) and non-housing investment. Then, consumption is similarly decomposed into durable consumption and non-durable consumption. The results suggest that housing investment responses might be the main reason for the difference between Australia and the Euro area. Regarding the difference between Australia and the U.S., because of the similarities in the impulse response functions in the VARs, the bigger share of consumption in total GDP in the U.S. is likely to be the main reason for the difference.

Knowledge on the differences of the output composition can help shed light on the empirical differences of the monetary policy transmission mechanism between countries. Furthermore, identifying the output composition dissimilarities and the main reasons behind is a step to better understand the process of the effects from a monetary policy shock to the specific real sectors, then the whole economy. This knowledge is informative for theories of the monetary policy transmission mechanisms.

The rest of this paper is structured as follows. First, the four VAR models to be used are described in Section II. Some explanations of available data will then be provided in Section III. Section IV presents the output composition results through impulse responses and contribution measures of consumption and investment, together with an exploration of the reasons behind the differences. Section V concludes. 


\section{VAR Models}

Following Sims (1980), many papers employ VAR models with different strategies of identification to investigate the monetary policy transmission mechanism. These include Bernanke and Blinder (1992), Eichenbaum (1992), Leeper and Gordon (1992), Gordon and Leeper (1994), Christiano and Eichenbaum (1992), and Leeper et al. (1996). Among those, Leeper et al. (1996) allow a non-recursive formation while Christiano et al. (1999) and others utilise recursive arrangements in the identification of monetary policy shocks. Some summaries of the literature of using parametric restrictions in identifying shocks for VAR models can be found in papers by Canova (1995), Bagliano and Favero (1998) and Christiano et al. (1999). A recent non-parametric strategy in identifying shocks emerges using sign restrictions, of which a review can be found in Fry and Pagan (2011).

Regarding the Australia case, Brischetto and Voss (1999) use a Structural VAR (SVAR) method similar to Kim and Roubini (1999) to examine the effects of monetary policy tools in Australia. Dungey and Pagan $(2000,2009)$ also estimate a SVAR model with restrictions emphasising some structural relations for the Australian economy. Some other authors such as Suzuki (2004) and Berkelmans (2005) examine the roles of each particular tool of monetary policy in Australia. Fry et al. (2008) use a SVAR model to examine the role of portfolio shocks in Australia while Fry et al. (2010) also use a SVAR model to investigate potential overvaluation in Australian housing and equity markets.

Output is specified as a single variable in almost all research on the transmission mechanism of monetary policy. Most frequently, output is measured by real GDP, the output gap or industrial production. The few papers that use VAR models to analyse the output composition of monetary policy transmission mechanisms do not cover Australia. The most relevant studies are by Angeloni et al. (2003), who analyse the output composition for the cases of the U.S. and the Euro area, and Fujiwara (2004), who explores the case of Japan. Meanwhile, Erceg and Levin (2006) decompose U.S. GDP into the durable sector (including durable consumption and residential investment) and other GDP components and find evidence in favour of strong responses of the durable sector to a contractionary monetary policy shock.

This paper utilises the four VAR models used by Angeloni et al. (2003) and Fujiwara (2004) to answer the first main question of whether there is any difference in the output composition of the monetary transmission mechanism between Australia and the U.S. and the Euro area. In this paper, GDP is decomposed into three separate variables: private consumption, private investment, and 'other GDP components' (which equals GDP minus consumption and investment, therefore includes government expenditure, net exports and small discrepancies). 
Following Angeloni et al. (2003) and Fujiwara (2004), a recursive Cholesky identification assumption is used in all of the VARs in this paper. As pointed out in Christiano et al. (1999), the recursive assumption justifies the estimation of monetary policy shocks by the fitted residuals in the OLS regression of the policy interest rate on the variables in the central banks' information set. This ordering assumes that all variables which are placed before the policy rate in the VARs are included in the central banks' contemporaneous information set. A policy rate shock can only instantly affect the variables placed after the policy rate in the VARs, while variables in the information set will respond with a lag.

The VAR(p) models, with the recursive identification assumption, can be written as follows:

$$
\begin{gathered}
Y_{t}=A_{0}+A_{1} Y_{t-1}+\ldots+A_{p} Y_{t-p}+e_{t} \\
e_{t}=B \varepsilon_{t} \\
Y_{t}=\left[\begin{array}{c}
Y_{1 t} \\
i_{t} \\
Y_{2 t}
\end{array}\right]
\end{gathered}
$$

in which $Y$ is the ( $k \times 1)$ vector of endogenous variables; $A_{0}$ is the ( $\left.k \times 1\right)$ vector of constant terms; $A_{1}, \ldots A_{p}$ are $(k \times k)$ matrices of parameters; $e$ is a ( $\left.k \times 1\right)$ vector of VAR error terms; $\varepsilon$ is a $(k \times 1)$ vector of zero-mean, serially and cross uncorrelated shocks; $B$ is a $k \times k$ lower triangular matrix with all diagonal terms equal to $1 ; i$ is the policy rate; $Y_{1}$ and $Y_{2}$ are vectors of variables which are placed before and after the policy rate respectively in the VARs.

The four models used in the comparison of this paper are versions of well-known VAR models of Christiano et al. (2005), Erceg and Levin (2006), and Peersman and Smets (2003). The models are described below.

First, the VAR developed by Christiano et al. (2005) is estimated ('Christiano-Eichenbaum-Evans VAR'). In this VAR, $Y_{1}$ includes six variables in the order: consumption, investment, other GDP components, CPI, real wages and labour productivity. $Y_{2}$ contains the profit-to-GDP ratio, money growth, and share price index.

Second, the VAR developed by Erceg and Levin (2006) is estimated ('Erceg-Levin VAR'). In this VAR, $Y_{1}$ includes consumption, investment, other GDP components, CPI, and commodity prices, while $Y_{2}$ is empty. Compared to the first VAR, commodity prices are included instead of real wages and labour productivity, but money growth and the share price index are not included. The Cholesky order of this VAR (with the policy rate placed last) assumes that a shock in the interest rate has no immediate effects on the other variables, while the central bank employs current information on all the other variables in targeting and implementing the interest rate. 
Third, a 'generalised Erceg-Levin VAR' is used, in which $Y_{1}$ includes consumption, investment, other GDP components, CPI, commodity prices, and bond yields, while money growth is the only variable included in $Y_{2}$. This identification scheme is similar to an expansion of the VAR used by Gordon and Leeper (1994).

Lastly, the model based on Peersman and Smets (2003) is used to account for the effects of the real exchange rate and also some exogenous factors ('Peersman-Smets VAR'). In this model $Y_{1}$ includes five endogenous variables: consumption, investment, other GDP components, CPI, and money growth; $Y_{2}$ includes the real effective exchange rate. For this VAR, a shock of the policy rate affects the exchange rate contemporaneously, and the central bank uses information on money growth together with all GDP components and prices in determining the policy rate. For Australia and the Euro area, three exogenous variables are used: the U.S. FED funds rate, U.S. GDP, and U.S. prices. Meanwhile, the oil price is the exogenous variable to be used for the U.S.

To take into account the fact that Australia is a small open economy while both the Euro area and the U.S. are 'big economies', the three exogenous variables in the Peersman-Smets VAR are also used in the first three VAR models for Australia. The models for the US and the Euro area are the same as in their original specification. That is, the four VAR models for Australia include exogenous variables, while exogenous variables appear only in the Peersman-Smets VAR for the two 'big' country comparators.

\section{Data}

The same sources of data as in Angeloni et al. (2003) for the Euro area (AWM database from European Central Bank) and the U.S. (from Moody’s www.freelunch.com) are used. For Australia, data come from Australian Bureau of Statistics (ABS) and Reserve Bank of Australia (RBA). The data sources are listed in the Appendix.

To conduct an international comparison with data for the same period, this paper uses quarterly data for the period 1982Q3-2007Q4. The sample includes 102 observations. The sample begins in quarter 3 of 1982 as the RBA index of commodity prices (G5 series from RBA) is available only from July 1982. Furthermore, as suggested by Angeloni et al. (2003), all impulse responses for the Euro area prior to 1980 are uncertain due to data problems. The end of the sample is chosen to avoid the Global Financial Crisis (GFC) which started in 2008 and had strong and prolonged effects for most countries/region of interest (although Australia did not technically experience a two-consecutive quarters of negative growth during 2008-2009). Excluding the recent GFC also avoids the period of unconventional monetary policy that has been implemented since the crisis period.

For Australia, the interbank rate is used for the policy rate, while the short term interest rate in the Area-Wide Model (AWM) database is used for the Euro area and the FED funds rate for the U.S. 
Money growth is measured as annualised money growth as in Angeloni et al. (2003) and Christiano et al. (2005). Except for money growth, the policy rate, and the profit-to-GDP ratio, all the other variables are natural logs of their levels. One or two lags are used for all VARs to conserve degrees of freedom. The Schwarz information criterion (SC) always points to 1 lag. In order to capture the dynamics of the variables with quarterly data, 2-lag structure is used when the VAR can produce stable impulse response functions, as in Angeloni et al. (2003). ${ }^{4}$

\section{Results}

\subsection{Output composition}

The question of whether Australia is different to the Euro area and the U.S. is examined in two aspects. First, the reactions of consumption and investment together with the other GDP components are assessed through the impulse response functions to a shock in the nominal policy rate in the VAR models, which can be named 'proportional effect'. Second, the shares of each component in total GDP are taken into account to compute the 'size effect'.

\subsubsection{Proportional effect}

Figure 1 shows the impulse responses to a shock in the policy rate in each of the four VAR models for Australia (1a), the Euro area (1b), and the U.S. (1c). The responses of consumption, investment, other GDP components, CPI, and the policy rate are shown. The thick lines demonstrate the impulse responses based on the point estimates, while the blurred lines illustrate the confidence intervals using the $10^{\text {th }}$ (lower) and $90^{\text {th }}$ (upper) percentile values of 1000 bootstrap simulations. ${ }^{5}$ The size of the positive shock in the nominal interest rate is computed according to Cholesky one-standard-deviation innovations, which are around 80 basis points for Australia, 30 basis points for the Euro area and 35 basis points for the U.S.

In general, the responses are of similar shape across the different VARs for each country. After a contractionary monetary policy shock, both consumption and investment decrease with some lags and stay significantly below zero before gradually coming back to their steady state levels. In terms of comparing the proportional effect between consumption and investment, some observations can be made as follows.

A common observation seen across models and countries/region is that the peak investment reaction exceeds the peak consumption reaction. In response to a Cholesky innovation shock in the policy rate, the peak investment reaction is around double the peak consumption reaction in the Euro

\footnotetext{
${ }^{4}$ A list of lag lengths to be used as well as some additional tables and figures can be found in the Web Appendices.

${ }^{5}$ In order to obtain impulse responses and confidence intervals using bootstraps for all the VAR models in this paper, I develop some codes building on the Python Macroeconomics Laboratory's codes.
} 
area, while in the U.S. it is more than triple and in Australia the investment peaks are nearly five times bigger than the consumption ones. ${ }^{6}$ For instance from Figure 1a, it is shown that a 80 basis point increase in the interbank rate in Australia leads to a decline of about $1-1.5 \%$ in private investment at peak, but only about $0.2-0.35 \%$ in private consumption at its maximum responses.

The second common point is that consumption responses stay significantly negative for a longer period compared to investment responses. In other words, investment comes back to its steady state levels quicker than consumption although investment peaks are deeper. For example, Figure 1a shows that after becoming significantly negative around the $4^{\text {th }}$ quarter, consumption responses in Australia stay significantly negative even after the $20^{\text {th }}$ quarter, while investment responses basically come back to be insignificant at around the $16^{\text {th }}$ quarter.

Some differences can be observed across countries. In terms of timing, investment reacts quicker and reaches its peak much sooner than consumption in Australia, while this is not necessarily the case for the Euro area and the U.S. Furthermore, both consumption and investment do decline from the first lag in Australia's VARs while either consumption or investment, or even both, can be seen to increase in the first quarter before beginning to decline in the Euro area and the U.S.

The impulse responses of the other GDP components vary across models and countries/region. A suggested theoretical channel is that when interest rates are higher, the return on domestic assets increases relative to foreign assets. Then in a world with capital mobility, more foreign currencies tend to flow in to buy domestic assets, resulting in an appreciation of the domestic currency. As a result, domestic goods become more expensive relative to foreign goods, and net exports decline (see Boivin et al., 2011). I have also decomposed the 'other GDP components' into government expenditure and net exports to explore this hypothesis. However, the net exports responses indicate an increase in almost all VARs, though the increases are insignificant for Australia and the Euro area. This might come from a depreciation of the domestic currency in responses to a contractionary monetary policy shock (rather than appreciation) that is commonly found in VAR models for industrial economies (Sims, 1992; Grilli \& Roubini, 1996; and Racette \& Raynauld, 1992). ${ }^{7}$

The impulse responses also demonstrate evidence of the 'price puzzle' for all countries of interest, in which prices increases in response to a positive shock in the nominal interest rate. This result is similar to what Angeloni et al. (2003) and Fujiwara (2004) find for earlier data in the U.S. and Japan with the same VAR identifications. As suggested in Barth and Ramey (2001), Ravenna and Walsh

\footnotetext{
${ }^{6}$ The confidence intervals are overlapping for most of the times, therefore the responses of consumption and investment are not really 'significantly different' from each other.

${ }^{7}$ Different identifications with more restrictions and an inclusion of terms of trade might be needed to address this 'puzzle'. However, it is outside the scope of this paper and might be a topic for future research. To save space, the impulse responses from VARs with net exports are included in the Web Appendices that can be found on the author's website.
} 
(2006), Chowdhury et al. (2006), Christiano et al. (2005), Gaiotti and Secchi (2006), Tillman (2008, 2009), and Ali and Anwar (2013), this can be regarded as empirical evidence of the importance of the 'cost channel', or the 'supply-side effects' in the monetary policy transmission mechanism. ${ }^{8}$ Unfortunately there has not been any extensive research on the existence of the cost channel in Australia. Another possible explanation for the 'price puzzle' for the case of Australia will be discussed later when housing investment is introduced to explore the second question of this paper.

In summary, a positive shock in the nominal policy rate leads to declines in both consumption and investment, which is consistent with theory. The maximum responses of investment are larger, indicating that the proportional effect of an increase in the policy rate on investment is larger than on consumption, or the investment channel is dominant compared to the consumption channel in proportional changes. However, the effects on consumption last longer than the effects on investment.

In addition, Granger causality tests are also implemented to check whether the interest rate Granger causes consumption and investment. According to the tests, in Australia the interest rate Granger causes investment but does not cause consumption at the $10 \%$ significance level. In the U.S., the interest rate causes investment at the $1 \%$ significance level and still does not cause consumption even at $10 \%$. This result might support the hypothesis that investment is more directly affected by interest rate changes compared to consumption in Australia and the U.S. It is slightly different in the Euro area where the tests show that the interest rate causes both investment and consumption at $1 \%$ significance level.

\footnotetext{
${ }^{8}$ Since firms must borrow to finance their payment to their factors of production before they receive revenues from sales, an increase in the policy rate would raise firms' production costs and therefore affect supply (AS). This supply-side effect would bring the price level up rather than down as in the demand side in a classical AD-AS model.
} 
FIGURE 1

Impulse Responses to a one standard deviation shock to the policy rate from the four VAR models (1982Q3-2007Q4, 20 quarter horizon, confidence intervals drawn using the $10^{\text {th }}$ (lower) and 90 ${ }^{\text {th }}$ (upper) percentile values of 1000 bootstrap simulations; 'Policy rate' unit is basis point, all the rest are \%)

1a. Australia

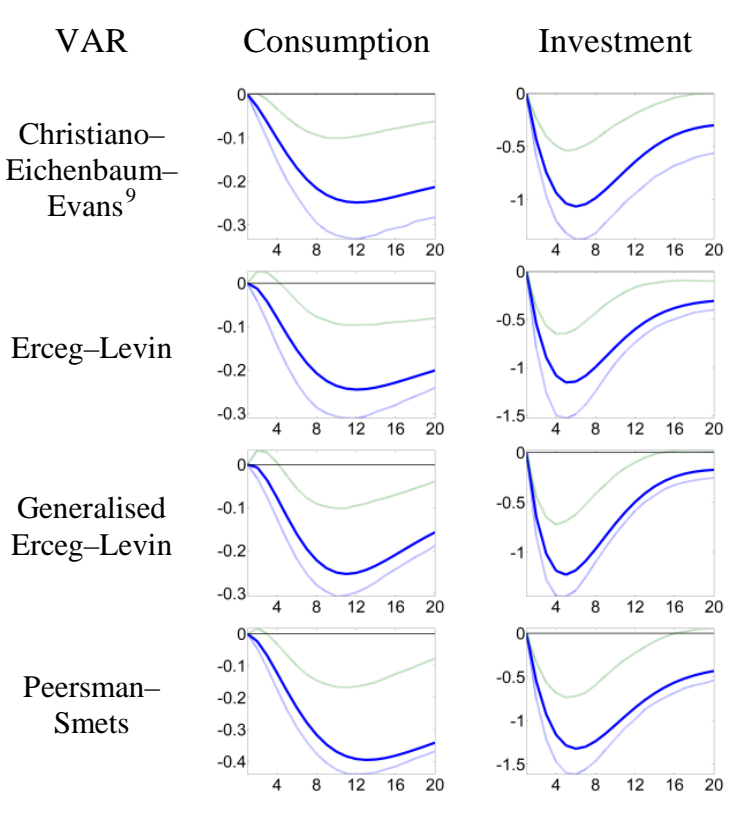

Other GDP
components
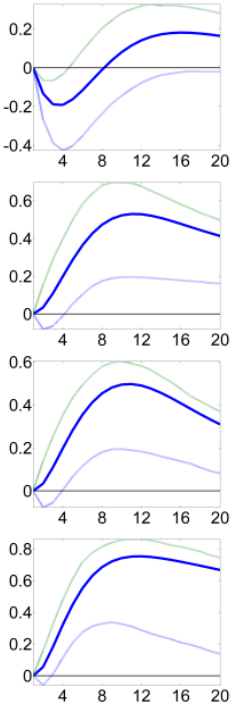

\section{1b. Euro area}

VAR
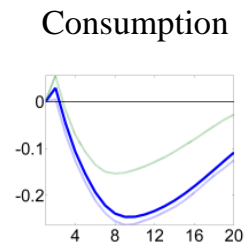

Erceg-Levin

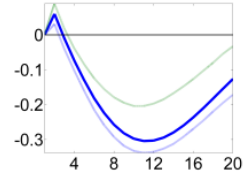

Generalised Erceg-Levin

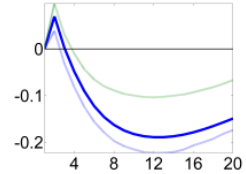

PeersmanSmets

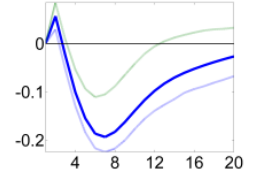

Investment

Other GDP
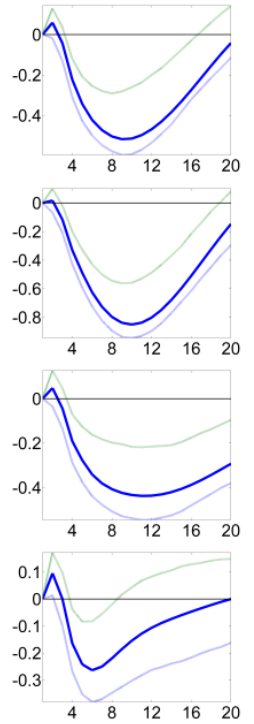

Christiano-

Evans

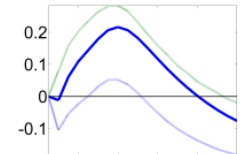

CPI
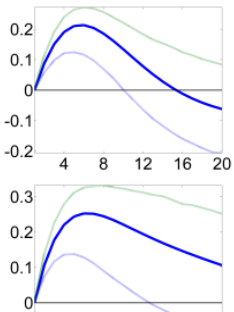

$\begin{array}{lllll}4 & 8 & 12 & 16 & 20\end{array}$
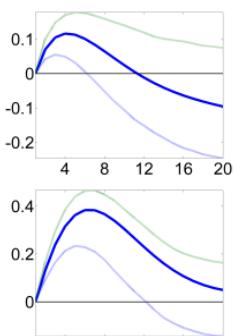

$\begin{array}{lllll}4 & 8 & 12 & 16 & 20\end{array}$ components

CPI
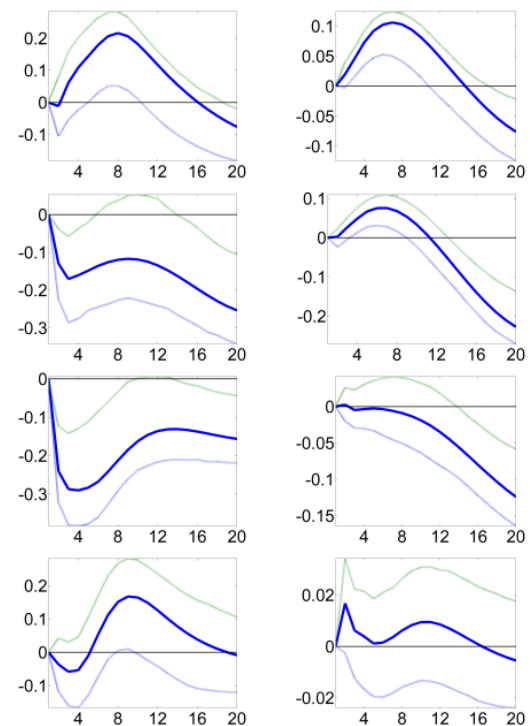

Policy rate
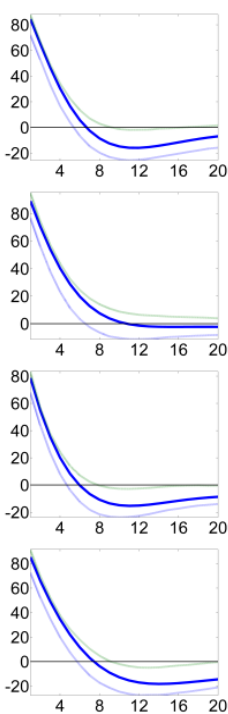

Policy rate
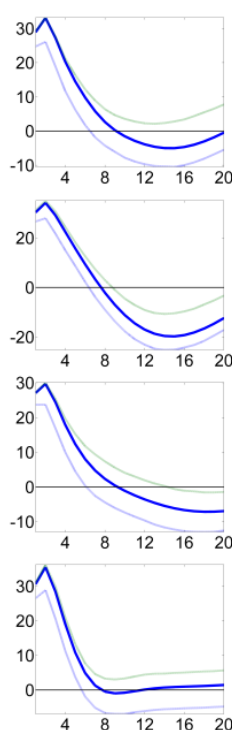

${ }^{9}$ For this specific VAR only, exogenous variables are opted out for producing stable impulse response functions. 


\section{1c. U.S.}
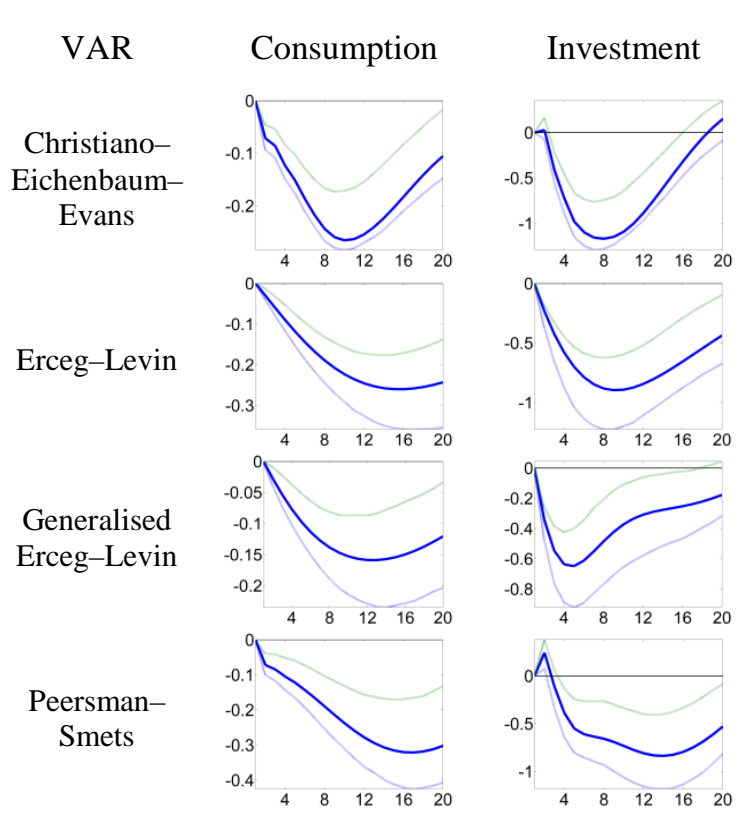

Other GDP components
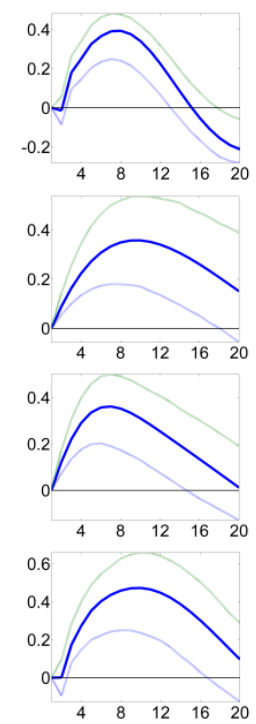

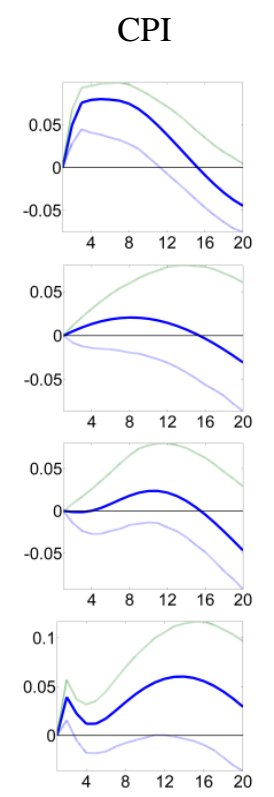

Policy rate
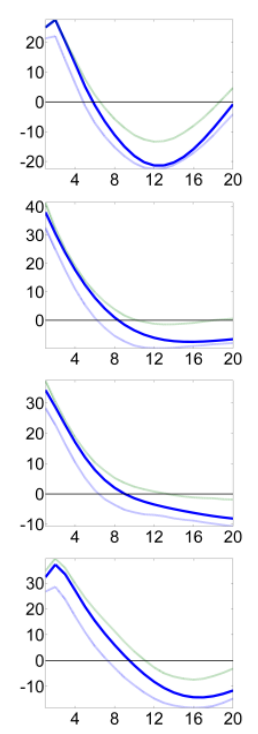

\subsubsection{Size effect}

In measuring the 'size effect', the impulse responses are weighted by contributions to the whole economy - for the consumption and investment channels. Similarly to Angeloni et al. (2003) and Fujiwara (2004), the size contributions of consumption and investment to the responses of private domestic demand, which is the sum of private consumption and private investment, are calculated via implementing a 2-step process:

Step 1: The responses of consumption and investment are transformed as ratios relative to the total GDP responses, in which consumption and investment movements are weighted by their shares in total GDP, which are listed in Table 1:

$$
\begin{aligned}
& C_{1}=\frac{C \times \text { weight }_{C}}{{\text { C } \times \text { weight }_{C}+I \times \text { weight }_{I}+G \times \text { weight }_{G}}} \\
& I_{1}=\frac{I \times \text { weight }_{I}}{{\text { C } \times \text { weight }_{C}+I \times \text { weight }_{I}+G \times \text { weight }_{G}}}
\end{aligned}
$$

where $C, I, G$ are responses of consumption, investment, and other GDP components respectively, which are estimated from each VAR and for each horizon.

TABLE 1

Shares of GDP components, 1982Q3-2007Q4

\begin{tabular}{cccc}
\hline Country/Region & Consumption & Investment & Other GDP components \\
\hline Australia & 0.54 & 0.17 & 0.29 \\
Euro area & 0.57 & 0.21 & 0.22 \\
U.S. & 0.65 & 0.16 & 0.19 \\
\hline
\end{tabular}


Step 2: Those numbers from step $1\left(C_{1}, I_{1}\right)$ are normalised so that they add up to one, then the contributions of consumption and investment in the private domestic demand are correspondingly:

$$
\begin{aligned}
& C_{2}=\frac{C_{1}}{C_{1}+I_{1}} \\
& I_{2}=\frac{I_{1}}{C_{1}+I_{1}}
\end{aligned}
$$

where $C_{2}$ and $I_{2}$ are the 'contributions', or 'size contributions' of consumption and investment respectively. This procedure helps us compare directly the size contributions between consumption and investment. A larger contribution means the more important channel in the output responses to the monetary policy shock.

Since $C_{2}+I_{2}=1$, it is only necessary to look at either $C_{2}$ or $I_{2}$. Table 2 shows the measures of the contributions of consumption $\left(C_{2}\right)$ based on the four VAR models at 4, 8, and 12 quarters. The calculations include the point estimates, together with the $10^{\text {th }}, 50^{\text {th }}$, and $90^{\text {th }}$ percentiles from 1000 bootstrap simulations for each of the four VARs. Normally, $C_{2}, I_{2} \in[0,1]$, however some numbers might be either negative or greater than 1 (outside of the interval $[0,1]$ ), indicating that consumption and investment are responding in opposite directions at those periods (which are mostly early periods, at 1-4 quarters, for the $10^{\text {th }}$ percentiles).

In addition to Table 2, Figure 2 shows the size contribution of consumption with confidence intervals where the median percentile is used as the main estimates (the thick lines) while the confidence intervals (the blurred lines) are drawn using $10^{\text {th }}$ (lower) and $90^{\text {th }}$ (upper) percentiles of 1000 bootstrap simulations. This figure can be used to formally test whether consumption contribution $\left(C_{2}\right)$ is higher or lower than 0.5 with $90 \%$ confidence.

Table 2 and Figure 2 indicate that in Australia, $C_{2}$ is significantly less than 0.5 from the $4^{\text {th }}$ quarter onward in almost all four VARs, meaning that the investment channel is dominant compared to the consumption channel in terms of the size effect. In the Euro area and U.S., $C_{2}$ is basically around 0.5 and sometimes can be significantly higher than 0.5 , especially in longer horizon (after 12 quarters). In Erceg-Levin and generalised Erceg-Levin VARs, $C_{2}$ in the Euro area and the U.S. can be less than 0.5 for the period between 4 and 12 quarters, but still higher than the corresponding $C_{2}$ in Australia. This result means when the shares of GDP are taken into account, Australia's case is different compared to the Euro area and the U.S., where the two channels are generally equally important. The relative contributions in the U.S. and the Euro area are similar.

Generally, it is concluded from all the four VAR models that in terms of both proportional effect (impulse responses) and size effect, the investment channel plays a more important role compared to the consumption channel for the monetary policy transmission mechanism in Australia. Meanwhile, although the investment responses are bigger at peaks, when the sizes are accounted for, the two 
channels are basically equal in the U.S. and the Euro area. These results indicate that the evidence of an 'output composition puzzle' as raised by Angeloni et al. (2003) becomes unclear when the recent data are investigated. To check for robustness, the order of the variables is changed so that the other GDP components are put before consumption and investment in the VARs. The main conclusions remain unchanged.

TABLE 2

Size contribution of consumption in the private domestic demand $\left(C_{2}\right)$ from the four VARs (10th, 50th, and 90th percentiles are calculated basing on 1000 bootstrap simulations)

\begin{tabular}{|c|c|c|c|c|c|c|c|c|c|c|c|c|c|}
\hline \multirow{3}{*}{ VAR } & \multirow{3}{*}{ Quarter } & \multicolumn{4}{|c|}{ Australia } & \multicolumn{4}{|c|}{ Euro area } & \multicolumn{4}{|c|}{ U.S. } \\
\hline & & \multirow{2}{*}{$\begin{array}{c}\text { Point } \\
\text { estimate }\end{array}$} & \multicolumn{3}{|c|}{ Percentile } & \multirow{2}{*}{$\begin{array}{c}\text { Point } \\
\text { estimate }\end{array}$} & \multicolumn{3}{|c|}{ Percentile } & \multirow{2}{*}{$\begin{array}{c}\text { Point } \\
\text { estimate }\end{array}$} & \multicolumn{3}{|c|}{ Percentile } \\
\hline & & & $10^{\text {th }}$ & $50^{\text {th }}$ & $90^{\text {th }}$ & & $10^{\text {th }}$ & $50^{\text {th }}$ & $90^{\text {th }}$ & & $10^{\text {th }}$ & $50^{\text {th }}$ & $90^{\text {th }}$ \\
\hline \multirow{3}{*}{$\begin{array}{l}\text { Christiano- } \\
\text { Eichenbaum- } \\
\text { Evans }\end{array}$} & $4^{\text {th }}$ & 0.23 & 0.10 & 0.20 & 0.24 & 0.58 & 0.52 & 0.57 & 0.83 & 0.46 & 0.48 & 0.51 & 0.59 \\
\hline & $8^{\text {th }}$ & 0.31 & 0.24 & 0.29 & 0.31 & 0.56 & 0.54 & 0.56 & 0.61 & 0.45 & 0.44 & 0.45 & 0.47 \\
\hline & $12^{\text {th }}$ & 0.38 & 0.33 & 0.36 & 0.37 & 0.57 & 0.54 & 0.57 & 0.61 & 0.48 & 0.47 & 0.48 & 0.50 \\
\hline \multirow{3}{*}{ Erceg-Levin } & $4^{\text {th }}$ & 0.16 & -0.11 & 0.11 & 0.18 & 0.31 & -0.51 & 0.21 & 0.98 & 0.38 & 0.30 & 0.32 & 0.34 \\
\hline & $8^{\text {th }}$ & 0.27 & 0.10 & 0.24 & 0.28 & 0.43 & 0.40 & 0.42 & 0.43 & 0.43 & 0.39 & 0.39 & 0.40 \\
\hline & $12^{\text {th }}$ & 0.35 & 0.24 & 0.33 & 0.35 & 0.47 & 0.46 & 0.46 & 0.46 & 0.48 & 0.45 & 0.45 & 0.46 \\
\hline \multirow{3}{*}{$\begin{array}{c}\text { Generalised } \\
\text { Erceg-Levin }\end{array}$} & $4^{\text {th }}$ & 0.14 & -0.11 & 0.08 & 0.16 & 0.28 & -0.60 & 0.30 & 1.42 & 0.32 & 0.21 & 0.26 & 0.29 \\
\hline & $8^{\text {th }}$ & 0.27 & 0.11 & 0.23 & 0.28 & 0.47 & 0.44 & 0.46 & 0.47 & 0.43 & 0.37 & 0.38 & 0.39 \\
\hline & $12^{\text {th }}$ & 0.36 & 0.25 & 0.34 & 0.36 & 0.51 & 0.50 & 0.50 & 0.52 & 0.51 & 0.46 & 0.47 & 0.51 \\
\hline \multirow{3}{*}{$\begin{array}{l}\text { Peersman- } \\
\text { Smets }\end{array}$} & $4^{\text {th }}$ & 0.22 & 0.03 & 0.16 & 0.21 & 0.66 & 0.10 & 0.57 & 0.90 & 0.66 & 0.59 & 0.76 & 1.41 \\
\hline & $8^{\text {th }}$ & 0.33 & 0.23 & 0.29 & 0.32 & 0.68 & 0.60 & 0.67 & 0.92 & 0.57 & 0.52 & 0.57 & 0.70 \\
\hline & $12^{\text {th }}$ & 0.41 & 0.36 & 0.39 & 0.39 & 0.69 & 0.60 & 0.67 & 0.98 & 0.57 & 0.54 & 0.57 & 0.65 \\
\hline
\end{tabular}

FIGURE 2

Size contribution of consumption in the private domestic demand $\left(C_{2}\right)$ from the four VARs (20 quarter horizon, the thick lines are the $50^{\text {th }}$ percentile values of $C_{2}$, the blurred lines are the confidence intervals drawn using the $10^{\text {th }}$ (lower) and $90^{\text {th }}$ (upper) percentile values of 1000 bootstrap simulations)

VAR

Christiano-

Eichenbaum-

Evans

Erceg-Levin

Generalised

Erceg-Levin

Peersman-

Smets
Australia
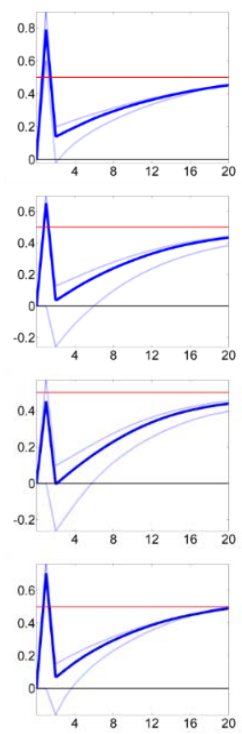

Euro area
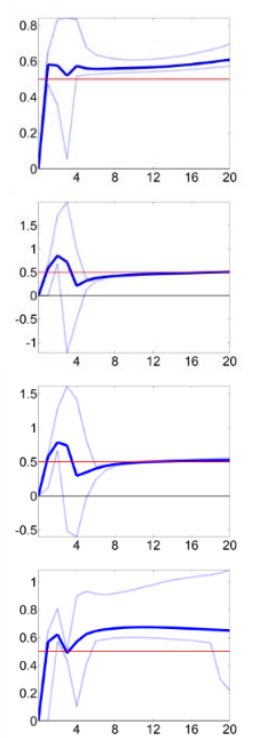

U.S.
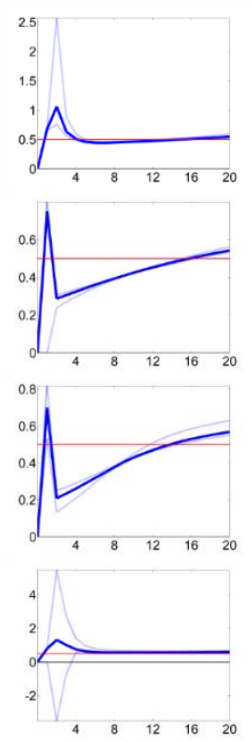


\subsection{Housing and non-housing investment responses}

The second task now is to find out the main reason behind the difference in the output composition in Australia compared to the case in the Euro area and the U.S. From the definition of the contributions $\left(C_{2}\right.$ and $\left.I_{2}\right)$ in equations (4) and (5), the reason might come from one of two sources: the proportional effect or the size effect.

In terms of proportional effect, as mentioned in subsection 4.1.1, at the peaks of the four VAR models, the consumption reaction in Australia is around five times smaller than that of investment, while it is around three times smaller in the U.S. and only half as small as in the Euro area. Therefore one can order the Euro area the strongest in terms of relative responses of consumption compared to investment, then the U.S., and finally Australia.

In terms of size effect, Table 1 shows that the relative size ratio of consumption to investment is 3.2:1, 2.7:1, and 4.1:1 respectively for Australia, the Euro area, and the U.S. This means that in terms of the relative size of consumption to investment, the U.S. is the biggest, then Australia, and the Euro area.

By combining the size and proportional effects, why the consumption channel is weakest in Australia compared to the comparators can be inferred. The next logical step therefore is to determine the factors behind the differences in the 'proportional effect', given the shares of consumption and investment in the total GDP. As suggested by Angeloni et al. (2003) and Fujiwara (2004), it is supposed that housing (residential) investment, which is the more-interest-rate-sensitive component in the total private investment, might be the key candidate.

For this purpose, private investment is decomposed into housing (residential) investment and nonhousing investment. The same four VAR models are estimated, with the same sets of exogenous variables for Australia (in all VARs), the Euro area, and the U.S. (in the Peersman-Smets VAR) as implemented in section $4.1 .^{10}$

Figure 3 shows the impulse responses (proportional effect) of housing and non-housing investment to a shock in the policy rate for the three countries/region. ${ }^{11}$ In Australia, housing investment responds more significantly and strongly at peaks compared to non-housing investment in all models. A similar pattern can be observed for the U.S. These results are similar to the ones found by Erceg and Levin (2006) who decompose the U.S. GDP into 'durable sector' and 'other GDP components' and conclude

\footnotetext{
${ }^{10}$ With the VAR models used in this paper, only the direct effects from interest rate to new housing supply (housing investment) are measured. A detailed survey on a set of other direct and indirect effects on housing markets (including user cost of capital, house price expectations, house-and-equity-price wealth effects, credit channel effects on consumer spending and housing demand) can be found in Mishkin (2007).

${ }^{11}$ The definition of the policy rate shocks are the same and the size of the shocks in the VARs are similar to the previous part. 
that the durable sector reacts more strongly. However, the opposite is true of the Euro area, where housing investment reacts weaker at peaks and less significantly to an interest rate shock compared to non-housing investment. Musso et al. (2011) also find that the residential investment responds more strongly in the U.S. compared to the Euro area after a contractionary monetary policy shock. This result might be explained by the fact that the levels of mortgage market development in the U.S. and Australia are much higher than in most of the countries in the Euro area (IMF, 2008; and Calza et al., 2013), therefore housing investment is actually more sensitive to interest rate changes.

\section{FIGURE 3}

Impulse Responses of housing and non-housing investment to a policy rate shock from VARs (1982Q3-2007Q4, 20 quarter horizon, confidence intervals drawn using the $10^{\text {th }}$ (lower) and $90^{\text {th }}$ (upper) percentile values of 1000 bootstrap simulations)

\begin{tabular}{|c|c|c|c|c|c|c|}
\hline \multirow{2}{*}{$\begin{array}{l}\text { VAR } \\
\text { models }\end{array}$} & \multicolumn{2}{|c|}{ Australia } & \multicolumn{2}{|c|}{ Euro area } & \multicolumn{2}{|c|}{ U.S. } \\
\hline & $\begin{array}{c}\text { Housing } \\
\text { investment }\end{array}$ & $\begin{array}{c}\text { Non-housing } \\
\text { investment }\end{array}$ & $\begin{array}{c}\text { Housing } \\
\text { investment }\end{array}$ & $\begin{array}{c}\text { Non-housing } \\
\text { investment }\end{array}$ & $\begin{array}{c}\text { Housing } \\
\text { investment }\end{array}$ & $\begin{array}{l}\text { Non-hor } \\
\text { investn }\end{array}$ \\
\hline \multicolumn{7}{|l|}{$\begin{array}{c}\text { Christiano- } \\
\text { Eichenbau } \\
\text { m-Evans }\end{array}$} \\
\hline \multicolumn{7}{|l|}{$\begin{array}{l}\text { Erceg- } \\
\text { Levin }\end{array}$} \\
\hline \multicolumn{7}{|l|}{$\begin{array}{c}\text { Generalised } \\
\text { Erceg- } \\
\text { Levin }^{12}\end{array}$} \\
\hline \multicolumn{7}{|l|}{$\begin{array}{l}\text { Peersman- } \\
\text { Smets }\end{array}$} \\
\hline \multicolumn{7}{|c|}{$\begin{array}{c}\text { TABLE } 3 \\
\text { Shares of housing and non-housing investment, 1982Q3-2007Q4 }\end{array}$} \\
\hline \multirow{2}{*}{\multicolumn{2}{|c|}{ Country/Region }} & \multicolumn{2}{|c|}{ Housing investment } & \multicolumn{3}{|c|}{ Non-housing investment } \\
\hline & & $\begin{array}{c}\text { In total } \\
\text { GDP }\end{array}$ & $\begin{array}{l}\text { In total private } \\
\text { investment }\end{array}$ & In total & $\begin{array}{r}\text { In to } \\
\text { in } \\
\end{array}$ & $\begin{array}{l}\text { l private } \\
\text { stment }\end{array}$ \\
\hline Aus & alia & 0.06 & 0.35 & 0.1 & & .65 \\
\hline Euro & area & 0.075 & 0.36 & 0.13 & & .64 \\
\hline & & 0.05 & 0.31 & 0.1 & & .69 \\
\hline
\end{tabular}

\footnotetext{
12 The annualised growth rates of CPI and commodity prices are used for the U.S. to produce stable impulse response
} functions. The qualitative results are not affected. 
Combining the proportional effect with the measures of the size effect using shares of housing and non-housing in total private investment from Table 3, the relative contributions of housing investment in the three countries/region are shown in Table 4 and Figure 4.

Table 4 and Figure 4 show that housing investment's contribution in the Euro area is much weaker compared to in Australia and the U.S. In general, housing investment contributes more than its share in total private investment in Australia and the U.S. (35\% and 31\% respectively). Meanwhile housing investment's contribution is very small in the Euro area, much smaller than its share in total private investment (36\%), except for in the Peersman-Smets VAR.

Based on both the 'proportional effect' and the 'size effect', the difference in housing investment responses relative to non-housing investment responses might be the key reason behind the difference of private investment responses to a policy rate shock, therefore the key factor behind the output composition difference between Australia and the Euro area. Those housing investment responses and contributions are similar between Australia and the U.S. A more detailed study on the effects of monetary policy on the housing market in Australia, which relates to some research by Debelle (2004), Ellis (2006), Fry et al. (2010) is out of the scope of this paper.

The strong responses of housing investment might also help explain the 'price puzzle' in Australia as mentioned in part 4.1.1. After an increase in the policy rate, housing investment declines strongly, which likely leads to an increase in rents. Together with an increase in the mortgage rate ${ }^{13}$, and therefore a rise in mortgage repayments, the increases in rents could be an important mechanism to explain the rising CPI after a contractionary monetary policy shock, at least in the short run. However, it might need further examinations to confirm this mechanism.

\footnotetext{
${ }^{13}$ Mortgage interest payment has been removed from Australian Bureau of Statistics’ CPI basket since 1998Q3.
} 
TABLE 4

Size contributions of housing investment to the investment response

to a monetary policy shock from the VARs

(10th, 50th, and 90th percentiles are calculated basing on 1000 bootstrap simulations)

\begin{tabular}{|c|c|c|c|c|c|c|c|c|c|c|c|c|c|}
\hline \multirow{3}{*}{ VAR } & \multirow{3}{*}{ Quarter } & \multicolumn{4}{|c|}{ Australia } & \multicolumn{4}{|c|}{ Euro area } & \multicolumn{4}{|c|}{ U.S. } \\
\hline & & \multirow{2}{*}{$\begin{array}{c}\text { Point } \\
\text { estimate }\end{array}$} & \multicolumn{3}{|c|}{ Percentile } & \multirow{2}{*}{$\begin{array}{c}\text { Point } \\
\text { estimate }\end{array}$} & \multicolumn{3}{|c|}{ Percentile } & \multirow{2}{*}{$\begin{array}{c}\text { Point } \\
\text { estimate }\end{array}$} & \multicolumn{3}{|c|}{ Percentile } \\
\hline & & & $10^{\text {th }}$ & $50^{\text {th }}$ & $90^{\text {th }}$ & & $10^{\text {th }}$ & $50^{\text {th }}$ & $90^{\text {th }}$ & & $10^{\text {th }}$ & $50^{\text {th }}$ & $90^{\text {th }}$ \\
\hline \multirow{3}{*}{$\begin{array}{c}\text { Christiano- } \\
\text { Eichenbaum- } \\
\text { Evans }\end{array}$} & $4^{\text {th }}$ & 0.42 & 0.38 & 0.41 & 0.51 & -0.25 & -1.07 & -0.16 & 0.08 & 0.72 & 0.64 & 0.83 & 1.52 \\
\hline & $8^{\text {th }}$ & 0.43 & 0.40 & 0.43 & 0.56 & -0.09 & -0.38 & 0.00 & 0.12 & 0.50 & 0.47 & 0.53 & 0.68 \\
\hline & $12^{\text {th }}$ & 0.40 & 0.37 & 0.41 & 0.56 & -0.04 & -0.25 & 0.05 & 0.14 & 0.40 & 0.38 & 0.41 & 0.51 \\
\hline \multirow{3}{*}{ Erceg-Levin } & $4^{\text {th }}$ & 0.52 & 0.41 & 0.49 & 0.82 & -0.03 & -1.06 & -0.03 & 0.74 & -1.06 & -2.14 & -0.33 & 2.06 \\
\hline & $8^{\text {th }}$ & 0.51 & 0.44 & 0.51 & 0.74 & 0.07 & -0.09 & 0.09 & 0.15 & 8.21 & -2.98 & -0.03 & 3.57 \\
\hline & $12^{\text {th }}$ & 0.48 & 0.41 & 0.49 & 0.76 & 0.06 & -0.04 & 0.08 & 0.13 & 2.05 & -1.86 & 0.76 & 2.74 \\
\hline \multirow{3}{*}{$\begin{array}{l}\text { Generalised } \\
\text { Erceg-Levin }\end{array}$} & $4^{\text {th }}$ & 0.42 & 0.37 & 0.41 & 0.54 & 0.39 & 0.15 & 0.43 & 0.64 & 0.06 & -0.04 & 0.17 & 0.36 \\
\hline & $8^{\text {th }}$ & 0.45 & 0.40 & 0.46 & 0.60 & 0.29 & 0.33 & 0.34 & 0.35 & -0.70 & -1.71 & -0.15 & 1.94 \\
\hline & $12^{\text {th }}$ & 0.44 & 0.40 & 0.46 & 0.64 & 0.22 & 0.19 & 0.25 & 0.27 & -8.66 & -2.25 & 0.55 & 2.62 \\
\hline \multirow{3}{*}{$\begin{array}{c}\text { Peersman- } \\
\text { Smets }\end{array}$} & $4^{\text {th }}$ & 0.68 & 0.48 & 0.66 & 1.45 & 0.28 & 0.02 & 0.27 & 0.58 & 2.21 & -3.31 & 0.54 & 3.93 \\
\hline & $8^{\text {th }}$ & 0.60 & 0.48 & 0.59 & 0.96 & 0.37 & 0.35 & 0.40 & 0.59 & 0.87 & 0.55 & 0.85 & 2.15 \\
\hline & $12^{\text {th }}$ & 0.57 & 0.44 & 0.54 & 0.98 & 0.40 & 0.35 & 0.44 & 0.81 & 0.69 & 0.54 & 0.69 & 1.33 \\
\hline
\end{tabular}

FIGURE 4

Size contribution of housing investment to the investment response to a monetary policy shock from the VARs

(20 quarter horizon, the thick lines are the $50^{\text {th }}$ percentile values of $C_{2}$, the blurred lines are the confidence intervals drawn using the $10^{\text {th }}$ (lower) and $90^{\text {th }}$ (upper) percentile values of 1000 bootstrap simulations)

VAR

Christiano-

Eichenbaum-

Evans

Erceg-Levin

Generalised

Erceg-Levin

PeersmanSmets
Australia
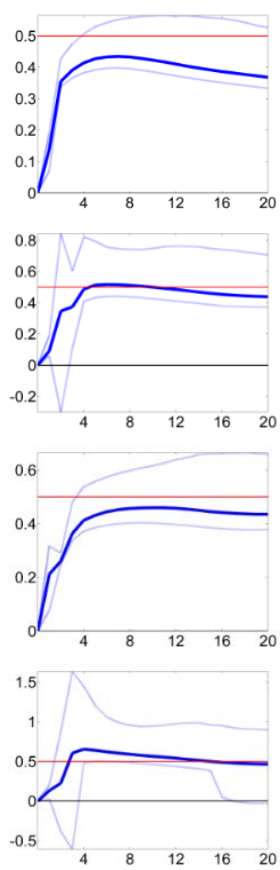

Euro area
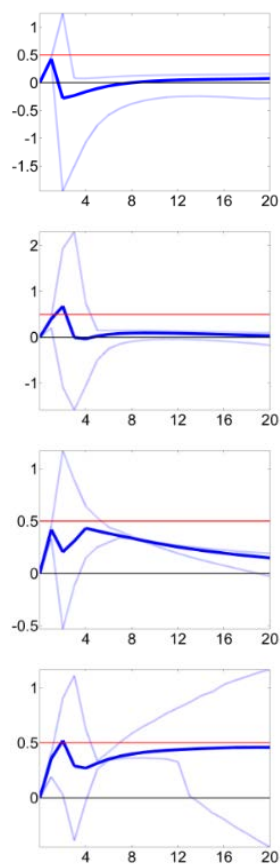

U.S.

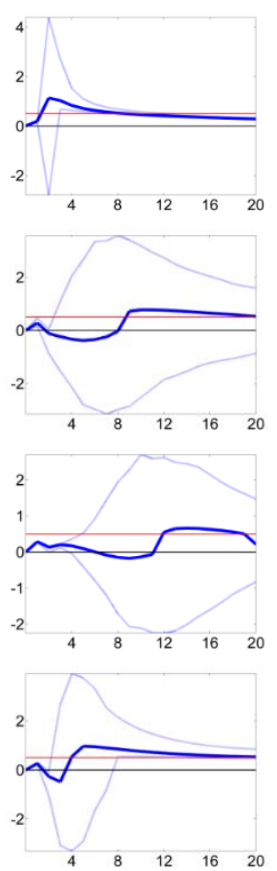




\subsection{Durable and non-durable consumption responses}

What is left now is to find the main reason for the difference between Australia and the U.S. For this purpose, private consumption is decomposed into durable consumption, which includes private consumption of durable goods: vehicles, furnishings and household equipment (more-interest-ratesensitive consumption) and non-durable consumption, for the two countries. It might be even clearer if the same could be done for the Euro area as well. However comparable data of durable and nondurable consumption are not available for the whole Euro area for the same period. Therefore this step is implemented for Australia and the U.S. only. Total private investment is now kept as a single variable. Once again, the same process of examining the proportional effects through impulse responses from the same VAR models (in Figure 5), then measuring the size effect using shares of durable and non-durable consumption in Table 5, is used to compare the relative contributions of durable consumption to non-durable consumption.

FIGURE 5

Impulse Responses of durable and non-durable consumption to a policy shock from VARs (1982Q3-2007Q4, 20 quarter horizon, confidence intervals drawn using the $10^{\text {th }}$ (lower) and $90^{\text {th }}$ (upper) percentile values of 1000 bootstrap simulations)

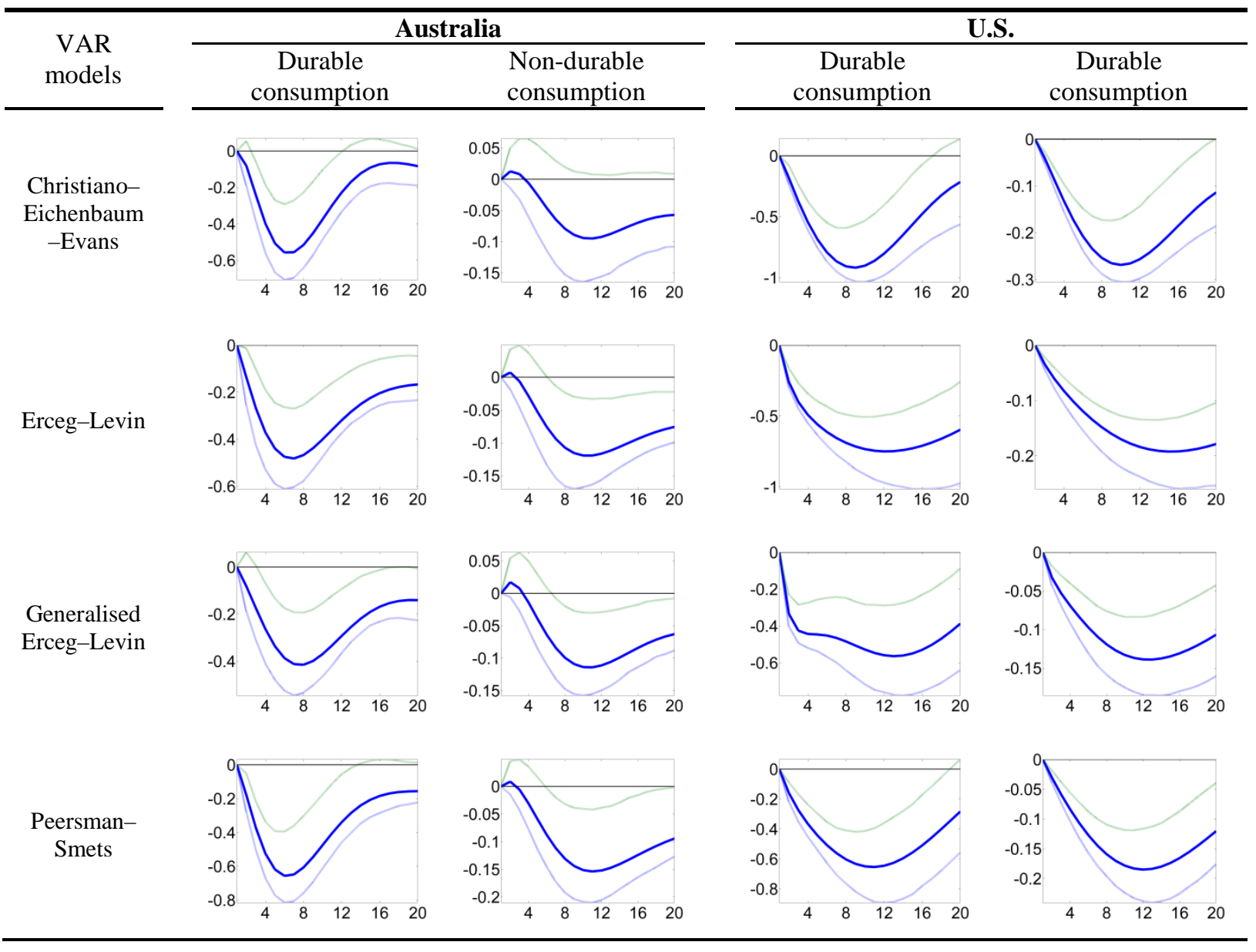


Figure 5 shows a similar relative impulse response pattern between Australia and the U.S. After a nominal interest rate shock, durable consumption responds more strongly at peaks and more significantly compared to non-durable consumption. The responses of durable consumption are around 4 times bigger than the responses of non-durable consumption at the peaks for both countries.

Given similar small shares of durable consumption in total private consumption from Table 5, Table 6 and Figure 6 show the contribution of durable consumption in the relative comparison to nondurable consumption. Durable consumption contributions are observed to be around $0.3-0.4$ for both Australia and the U.S. in all VAR models (although the confidence intervals are broader in Australia).

The similarities between the two countries both in terms of relative impulse responses and size contribution measures of durable consumption henceforth lead to the conclusion that the shares of consumption and investment in total GDP (shown in Table 1) might be the most important reason behind the difference of output composition in Australia and in the U.S.

TABLE 5

Shares of durable and non-durable consumption, 1982Q3-2007Q4

\begin{tabular}{|c|c|c|c|c|}
\hline \multirow[b]{2}{*}{ Country/Region } & \multicolumn{2}{|c|}{ Durable consumption } & \multicolumn{2}{|c|}{ Non-durable consumption } \\
\hline & $\begin{array}{c}\text { In total } \\
\text { GDP }\end{array}$ & $\begin{array}{l}\text { In total private } \\
\text { consumption }\end{array}$ & In total GDP & $\begin{array}{l}\text { In total private } \\
\text { consumption }\end{array}$ \\
\hline Australia & 0.04 & 0.075 & 0.50 & 0.925 \\
\hline U.S. & 0.055 & 0.085 & 0.595 & 0.915 \\
\hline
\end{tabular}

TABLE 6

Contributions of durable consumption to the response to a monetary policy shock (10th, 50th, and 90th percentiles are calculated basing on 1000 bootstrap simulations)

\begin{tabular}{|c|c|c|c|c|c|c|c|c|c|}
\hline \multirow{3}{*}{ VAR } & \multirow{3}{*}{ Quarter } & \multicolumn{4}{|c|}{ Australia } & \multicolumn{4}{|c|}{ U.S. } \\
\hline & & \multirow{2}{*}{$\begin{array}{c}\text { Point } \\
\text { estimate }\end{array}$} & \multicolumn{3}{|c|}{ Percentile } & \multirow{2}{*}{$\begin{array}{c}\text { Point } \\
\text { estimate }\end{array}$} & \multicolumn{3}{|c|}{ Percentile } \\
\hline & & & $10^{\text {th }}$ & $50^{\text {th }}$ & $90^{\text {th }}$ & & $10^{\text {th }}$ & $50^{\text {th }}$ & $90^{\text {th }}$ \\
\hline \multirow{3}{*}{$\begin{array}{l}\text { Christiano- } \\
\text { Eichenbaum- } \\
\text { Evans }\end{array}$} & $4^{\text {th }}$ & 0.90 & -1.08 & 0.42 & 1.61 & 0.28 & 0.26 & 0.27 & 0.28 \\
\hline & $8^{\text {th }}$ & 0.48 & -0.57 & 0.42 & 1.17 & 0.26 & 0.25 & 0.26 & 0.26 \\
\hline & $12^{\text {th }}$ & 0.35 & -0.21 & 0.32 & 0.74 & 0.25 & 0.24 & 0.25 & 0.25 \\
\hline \multirow{3}{*}{ Erceg-Levin } & $4^{\text {th }}$ & 0.55 & -0.96 & 0.47 & 1.64 & 0.36 & 0.35 & 0.36 & 0.37 \\
\hline & $8^{\text {th }}$ & 0.34 & -0.02 & 0.38 & 0.85 & 0.33 & 0.31 & 0.32 & 0.32 \\
\hline & $12^{\text {th }}$ & 0.27 & 0.23 & 0.30 & 0.56 & 0.30 & 0.29 & 0.30 & 0.30 \\
\hline \multirow{3}{*}{$\begin{array}{l}\text { Generalised } \\
\text { Erceg-Levin }\end{array}$} & $4^{\text {th }}$ & 0.71 & -0.92 & 0.10 & 1.16 & 0.39 & 0.39 & 0.41 & 0.45 \\
\hline & $8^{\text {th }}$ & 0.34 & -0.28 & 0.35 & 0.90 & 0.32 & 0.32 & 0.32 & 0.32 \\
\hline & $12^{\text {th }}$ & 0.26 & 0.22 & 0.28 & 0.55 & 0.30 & 0.29 & 0.29 & 0.30 \\
\hline \multirow{3}{*}{$\begin{array}{l}\text { Peersman- } \\
\text { Smets }\end{array}$} & $4^{\text {th }}$ & 0.61 & -1.17 & 0.58 & 1.82 & 0.29 & 0.29 & 0.30 & 0.30 \\
\hline & $8^{\text {th }}$ & 0.37 & 0.30 & 0.41 & 0.96 & 0.27 & 0.27 & 0.27 & 0.28 \\
\hline & $12^{\text {th }}$ & 0.28 & 0.25 & 0.30 & 0.56 & 0.26 & 0.26 & 0.26 & 0.27 \\
\hline
\end{tabular}


FIGURE 6

Size contribution of durable consumption

(20 quarter horizon, the thick lines are the $50^{\text {th }}$ percentile values of $C_{2}$, the blurred lines are the confidence intervals drawn using the $10^{\text {th }}$ (lower) and $90^{\text {th }}$ (upper) percentile values of 1000 bootstrap simulations)

VAR

Christiano-

Eichenbaum-

Evans

Erceg-Levin

Generalised

Erceg-Levin

Peersman-

Smets
Australia
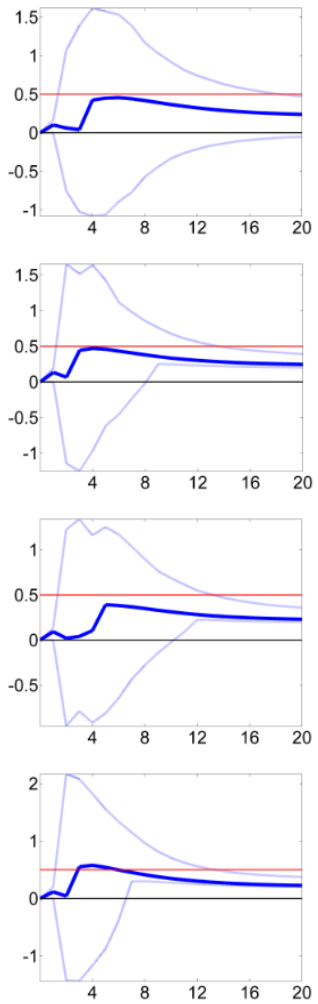

U.S.
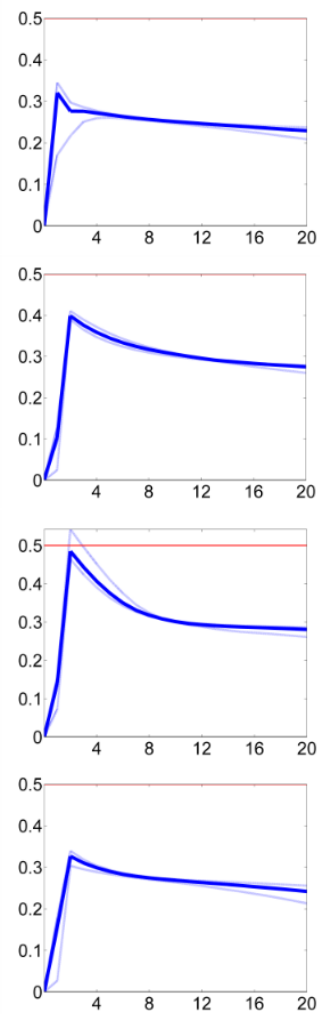

\section{Conclusion}

Using quarterly data for the period 1982Q3-2007Q4, four VAR models are estimated to compare the output composition of the monetary policy transmission mechanism in Australia, the Euro area, and the U.S. Possible determinants of the differences across countries/region are also explored by decomposing investment and consumption so as more-interest-rate-sensitive components (housing investment and durable consumption) are introduced. The results indicate that:

i) In terms of proportional effect, investment reacts more strongly than consumption at peaks for all countries/region. Consumption responses stay more significant for longer period and over a longer horizon. In Australia investment responds more quickly compared to consumption after a monetary policy shock.

ii) When the shares in total GDP are accounted for, the investment channel is dominant in Australia, while the two channels are not significantly different to each other in the Euro area and the U.S. 
iii) Housing investment might play the key role in explaining the difference between Australia and the Euro area, while the difference between Australia and the U.S. likely comes from different shares of consumption in total GDP.

For the purpose of this paper, the recursive assumption is used for identifying the monetary policy shocks in all the VAR models, which are used by the previous studies (Angeloni et al., 2003; Fujiwara, 2004). This identification strategy is not the best one for a SVAR model of Australia (for which Dungey \& Pagan, 2000 and 2009; Fry et al., 2008; and Fry et al., 2010 should be the most compelling candidates) but it might be a sound way for implementing an international comparison. Some further issues, such as the responses of net exports to a shock in monetary policy; the existence of the 'cost channel' in Australia; and the detailed effects of monetary policy on the housing market in Australia - which need different identification schemes to be examined extensively - are outside the scope of this paper and left for future research. 


\section{Appendix}

\section{Data sources}

\section{$\underline{\text { Australia }}$}

Consumption

Investment

\section{GDP}

Other GDP components

Government expenditure

Net exports

CPI

Real wages

Labour productivity

Policy rate

Profit to GDP ratio

M3

Share price index

Commodity prices

Bond yields

REER

Housing investment

Durable consumption

\section{$\underline{\text { Euro area }}$}

Housing investment

\section{U.S.}

GDP

Consumption

Investment

Other GDP components

CPI

Real wages

Labour productivity

Policy rate

Profit to GDP ratio

M2
RBA, G11 Gross Domestic Product - expenditure components, private spending, consumption, seasonal adjusted

RBA, G11 Gross Domestic Product - expenditure components, private spending, investment, seasonal adjusted

RBA, G10 Gross Domestic Product - GDP, 2009/10 chained volume measures, seasonal adjusted

RBA, GDP minus consumption and investment, seasonal adjusted

RBA, Other GDP components minus net exports, seasonal adjusted

RBA, G11 Gross Domestic Product - expenditure components, exports minus imports

RBA, G2 CPI, all groups, 1989/90 = 100, seasonal adjusted

RBA, G6 Labour costs - average weekly earnings, seasonal adjusted

GDP/hours worked from ABS, 6202.0 Labour Force, aggregate monthly hours worked, persons, seasonal adjusted

RBA, F1 Interest rates and yields - money market, interbank rate

Profits/GDP, profits from ABS, 5206.0 Table 7. Income from GDP, Gross operating surplus RBA, D3 Monetary aggregates, M3, seasonal adjusted

ASX All Ordinaries price index, Wren Research, http://www.wrenresearch.com.au/downloads/

RBA, G5 Index of Commodity prices, 2008/09 = 100, all items

RBA, F2 Capital market yields, Government bonds, 10 years

RBA, F15 Real exchange rate measures, real trade-weighted index, $1995=100$

ABS, 13500DO013_201204 Table 8- Table 3.4 - Private gross fixed capital formation and inventories, Private gross fixed capital formation, Dwellings, chain volume measures, seasonal adjusted

ABS, 13500DO013_201204 Table 2-Table 3.1 - Household final consumption expenditure, Purchases of vehicles plus furnishings and household equipment, chain volume measures, seasonal adjusted

All from Area-Wide Model (AWM17UP12) ${ }^{14}$, except:

Datastream, EKXIPRD.C, Oxford Economics, EK investment, private dwellings, real conn

RBA, I1 International GDP, seasonal adjusted; and U.S. Bureau of Economic Analysis (BEA), Gross Domestic Product, (Bil. Ch. 2009 USD, SAAR), http://www.economy.com/freelunch

U.S. Bureau of Economic Analysis (BEA), Personal Consumption Expenditures, (Bil. Ch. 2009

USD, SAAR), http://www.economy.com/freelunch

U.S. Bureau of Economic Analysis (BEA), Gross Private Domestic Investment, (Bil. Ch. 2009 USD,

SAAR), http://www.economy.com/freelunch

GDP minus Consumption and Investment

RBA, I2 International CPI, 1996 = 100; and U.S. Bureau of Labor Statistics, CPI: Urban Consumer All items, (Index 1982-84 = 100, seasonal adjusted), http://www.economy.com/freelunch Datastream, USWAGESPD, U.S. Bureau of Labor Statistics BLS, U.S. AVG HOURLY REAL EARN.OF PRODN. EMPLOYEES, 1982-84 prices, seasonal adjusted

U.S. Bureau of Labor Statistics (BLS), Business: All Persons - Output Per Hour, (Index 2005=100, seasonal adjusted), http://www.economy.com/freelunch

U.S. Board of Governors of the Federal Reserve System (FRB), Federal Funds Effective Rate, http://www.economy.com/freelunch

Profits/GDP; Profits: U.S. Bureau of Economic Analysis (BEA), U.S. profits after tax - corporate business

U.S. Board of Governors of the Federal Reserve System (FRB): H.6 Money Stock Measures, Money Stock: M2, (Bil. USD, seasonal adjusted), http://www.economy.com/freelunch

\footnotetext{
${ }^{14}$ I thank José Emilio Gumiel from DG - Research/ Monetary Policy Research Division, ECB for providing me with the latest AWM data.
} 
Share price index Commodity prices

Bond yields

\section{REER}

Housing investment

Durable consumption

Oil price
Standard and Poor's, S\&P 500 Stock Price Index, http://research.stlouisfed.org/fred2/ Bridge/CRB, KR-CRB Futures Price Index, (1967=100), http://www.economy.com/freelunch U.S. Board of Governors of the Federal Reserve System (FRB): H.15 Selected Interest Rates, Treasury Constant Maturities Nominal - 10 year, http://www.economy.com/freelunch Board of Governors of the Federal Reserve System, Real Trade Weighted U.S. Dollar Index: Broad, March 1973=100, http://research.stlouisfed.org/fred2/

U.S. Bureau of Economic Analysis (BEA), Private Fixed Investment: Residential, (Bil. Ch. 2009 USD, SAAR), http://www.economy.com/freelunch

U.S. Bureau of Economic Analysis (BEA), Personal Consumption Expenditures: Durable Goods, (Bil. Ch. 2009 USD, SAAR), http://www.economy.com/freelunch Dow Jones \& Company, Spot Oil Price: West Texas Intermediate, http://research.stlouisfed.org/fred2/ 


\section{REFERENCES}

Ali, S.Z. and Anwar, S. (2013), 'Inflation and Interest Rates in the Presence of a Cost Channel, Wealth Effect and Agent Heterogeneity', Economic Modelling, 31, 286-296.

Angeloni, I., Kashyap, A., Mojon, B. and Terlizzese, D. (2003), 'The Output Composition Puzzle: A Difference in the Monetary Transmission Mechanism in the Euro Area and U.S', Journal of Money, Credit and Banking, 35(6), 1265-1306.

Bagliano, F.C. and Favero, C.A. (1998), 'Measuring Monetary Policy with VAR Models: An Evaluation', European Economic Review, 42(6), 1069-1112.

Barth, M. and Ramey, V. (2001), 'The Cost Channel of Monetary Transmission', NBER Macroeconomic Annual (2001), ed. by B. Bernanke and K. Rogoff. Cambridge: MIT Press, 199-240.

Berkelmans, L. (2005), 'Credit and Monetary Policy: An Australian SVAR', Reserve Bank of Australia Discussion Paper, 2005-6.

Bernanke, B.S. and Blinder, A.S. (1992), 'The Federal Funds Rate and the Channels of Monetary Transmission', American Economic Review, 82(4), 901-921.

Boivin, J., Kiley, M.T. and Mishkin, F.S. (2010), 'How Has the Monetary Transmission Mechanism Evolved Over Time?', in Friedman, B.M. and Woodford, M. (eds), Handbook of Monetary Economics, edition 1, volume 3, chapter 8, Elsevier; 369-422.

Brischetto, A. and Voss, G. (1999), 'A Structural Vector Auto regression Model of Monetary Policy in Australia', mimeo, Reserve Bank of Australia.

Calza, A., Monacelli, T. and Stracca, L. (2013), 'Housing Finance and Monetary Policy', Journal of the European Economic Association, 11(S1), 101-122.

Canova, F. (1995), 'VAR: Specification, Estimation, Testing and Forecasting', in Pesaran H. and Wickens M. (eds), Handbook of Applied Econometrics. John Wiley and Sons; 31-65.

Christiano, L. and Eichenbaum, M. (1992), 'Liquidity Effects and the Monetary Transmission Mechanism’, American Economic Review, 82(2), 346-353.

Christiano, L., Eichenbaum, M. and Evans, C. (1999), 'Monetary Policy Shocks: What Have We Learned and to What End?', in Taylor, J.B. and Woodford, M. (eds), Handbook of Macroeconomics. Amsterdam, New York and Oxford: Elsevier Science, North-Holland; 65-148.

-- (2005), 'Nominal Rigidities and the Dynamic Effects of a Shock to Monetary Policy', Journal of Political Economy, 113(1), 1-45.

Debelle, G. (2004), 'Household Debt and the Macroeconomy', BIS Quarterly Review (March).

Dungey, M. and Pagan, A. (2000), 'A Structural VAR Model of the Australian Economy', Economic Record, 76, 321-342.

-- (2009), 'Extending a SVAR Model of the Australian Economy', Economic Record, 85, 1-20.

Eichenbaum, M. (1992), 'Comments on 'Interpreting the Macroeconomic Time Series Facts: the Effects of Monetary Policy’ by Christopher Sims', European Economic Review, 36(5), 1001-1011.

Ellis, L. (2006), 'Housing and Housing Finance: The View from Australia and Beyond', RBA Research Discussion Papers RDP2006-12, Reserve Bank of Australia.

Erceg, C. and Levin, A. (2006), 'Optimal Monetary Policy with Durable Consumption Goods', Journal of Monetary Economics, 53, 1341-1359.

Friedman, Milton (1956). 'A Theory of the Consumption Function', Princeton N. J.: Princeton University Press.

Fry, R., Hocking, J. and Martin, V. L. (2008), 'The Role of Portfolio Shocks in a Structural Vector Autoregressive Model of the Australian Economy', Economic Record, 84: 17-33.

Fry, R.A., Martin, V.L. and Voukelatos, N. (2010), 'Overvaluation in Australian Housing and Equity Markets: Wealth Effects or Monetary Policy?’, Economic Record, 86, 465-485.

Fry, R. and Pagan, A. (2011), 'Sign Restrictions in Structural Vector Autoregressions: A Critical Review', Journal of Economic Literature, 49(4), 938-960.

Fujiwara, I. (2004), 'Output Composition of the Monetary Policy Transmission Mechanism in Japan', The B.E. Journal of Macroeconomics, 0(1), Article 11. 
-- (2006), 'Evaluating Monetary Policy When Nominal Interest Rates Are Almost Zero', Journal of the Japanese and International Economies, 20, 434-453.

Gaiotti, E. and Secchi, A. (2006), 'Is There a Cost Channel of Monetary Policy Transmission? An Investigation into the Pricing Behavior of 2,000 Firms', Journal of Money, Credit and Banking, 38(8), 2013-2037.

Gordon, D. and Leeper, E. (1994), 'The Dynamic Impacts of Monetary Policy: An Exercise in Tentative Identification', Journal of Political Economy, 102, 1228-1247.

Hall, R. (1978), 'Stochastic Implications of the Life Cycle-Permanent Income Hypothesis: Theory and Evidence', Journal of Political Economy, 86, 971-988.

IMF (2008), 'The Changing Housing Cycle and the Implications for Monetary Policy', IMF World Economic Outlook, 103-132.

Iwata, S. and Wu, S. (2006), 'Estimating Monetary Policy Effects When Interest Rates Are Close To Zero', Journal of Monetary Economics, 53, 1395-1408.

Kim, S. and Roubini, N. (1999), 'Exchange Rate Anomalies in the Industrial Countries: A Solution with a Structural VAR Approach', mimeo, University of Illinois, Urbana-Champaign.

Leeper, E.M. and Gordon, D.B. (1992), 'In Search of the Liquidity Effect', Journal of Monetary Economics, 29(3), 341-369.

Leeper, E., Sims, C. and Zha, T. (1996), 'What Does Monetary Policy Do?', Brookings Papers on Economic Activity, 2, 1-63.

Mishkin, F.S., (2007), 'Housing and the Monetary Transmission Mechanism’, Proceedings, Federal Reserve Bank of Kansas City, 359-413.

Modigliani, F. and Brumberg, R. (1954), 'Utility Analysis and the Consumption Function: An Interpretation of Cross-section Data', in: Kurihara, K.K (ed.): Post-Keynesian Economics.

Musso, A., Neri, S. and Stracca, L. (2010), 'Housing, Consumption and Monetary Policy - How Different are the U.S. and the Euro Area?', European Central Bank Working Paper Series 1161.

Peersman, G. and Smets, F. (2003), 'The Monetary Transmission Mechanism in the Euro Area: More Evidence from VAR Analysis', in Angeloni, I., Kashyap, A. and Mojon B. (eds), Monetary Policy Transmission in the Euro Area. Cambridge: Cambridge University Press, 36-55.

Romer, D. (2011), 'Advanced Macroeconomics', McGraw Hill, $4^{\text {th }}$ edition.

Sims, C.A. (1980), 'Macroeconomics and Reality', Econometrica, 48, 1-48.

-- (1992), 'Interpreting the Macroeconomic Time Series: the Effects of Monetary Policy', European Economic Review, 36, 975-1000.

Stevens, G. (1999), 'Six Years of Inflation Targeting', address to the Economic Society of Australia. Available from http://www.rba.gov.au/speeches/1999/sp-ag-200499.html.

Suzuki, T. (2004), 'Is the Lending Channel of Monetary Policy Dominant in Australia?', Economic Record, 80, 145-156.

The Python Macroeconomics Laboratory (2008), 'Christiano VAR code' (free sources). Available from: http://pymaclab.googlecode.com/svn/trunk/data/Christiano/varcode/ or http://code.google.com/p/pymaclab/source/browse/trunk/data/Christiano/varcode/?r=2.

Tillman, P. (2008), 'Do Interest Rates Drive Inflation Dynamics? An Analysis of the Cost Channel of Monetary Transmission', Journal of Economic Dynamics \& Control, 32, 2723-2744.

Tillman, P. (2009), 'The Time-Varying Cost Channel of Monetary Transmission', Journal of International Money and Finance, 28, 941-953.

Uhlig, H. (2005), 'What are the Effects of Monetary Policy on Output? Results from an Agnostic Identification Procedure', Journal of Monetary Economics, 52, 381-419. 